\title{
Invasiveness of alien vascular plants in six arid zones of Europe, Africa and America
}

\author{
Mario Sanz Elorza (*), Francisco González Bernardo (**), \\ Alfredo Serreta Oliván (***) \& Laura P. Gavilán Iglesias (****)
}

\begin{abstract}
Sanz Elorza, M., González Bernardo, F., Serreta Oliván, A. \& Gavilán Iglesias, L.P. Invasiveness of alien vascular plants in six arid zones of Europe, Africa and America. Lazaroa 31: 109-126 (2010).

Biological invasions are one of the most important components of global change, and have increasing effects on the loss of biodiversity and on human societies as a whole. The difficulties of accurately predicting the fate of a given introduction has led to increased interest in identifying situations where the risk posed by invaders is particularly high. We analyse patterns of plant invasions in arid zones to develop explicit invasion risk protocols. The study zones are five arid regions in three continents: the Mojave and Sonoran Deserts in North America, the Atacama Desert in South America, the Sahara in northern Africa and the Tabernas and Monegros in southwest Europe, (Spain). We test which life-history traits are related to invasiveness in these areas. We use Generalized Linear Mixed Models (GLMM) to model variation between species in invasion success as a function of eight predictors, potentially related to invasiveness: clonality, pollination model, dispersal syndrome, linking to moist soils, seed size, linking to disturbed habitats, salinity tolerance and longevity. We also analyse the differences that exist between the total alien flora in these six areas of the world with respect to the attributes that were considered. From the species perspective, when taxonomic effects were accounted for, only dispersal syndrome and linking to disturbed habitats appeared to be related to the invasive nature of plants. However, if taxonomic effects are not taken into account the variable salinity tolerance is also significantly related. In spite of the fact that the regions have important climatic analogies, there does not appear to be a clear general pattern in the attributes of alien flora, as these are largely dependent on local conditions.
\end{abstract}

Key words: plant invasions, alien flora, arid zones.

Resumen: Sanz Elorza, M., González Bernardo, F., Serreta Oliván, A. \& Gavilán Iglesias, L.P. Capacidad invasora de las plantas vasculares alóctonas en seis zonas áridas de Europa, África y América. Lazaroa 31: 109-126 (2009).

Las invasions biológicas constituyen en la actualidad uno de los factores más influyentes del cambio global, con evidente influencia tanto en la pérdida de biodiversidad como en las actividades del ser humano. Ante la dificultad de predecir la ocurrencia de estas invasiones, cada vez va cobrando mayor interés la identificación de áreas especialmente susceptibles de ser invadidas. En este trabajo, analizamos los atributos de las plantas alóctonas invasoras de zonas áridas en aras a establecer las bases científicas que permitan identificar y valorar las situaciones de riesgo. Se han elegido para este estudio seis zonas áridas situadas en tres continentes: los desiertos de Mojave y Sonora en América del Norte, el desierto de Atacama en América del Sur, el desierto del Sahara en el norte de África y los subdesiertos de Tabernas y Los Monegros en el suroeste de Europa (España). Hemos estudiado los atributos vitales que parecen estar más relacionados con su capacidad invasora en zonas áridas. Hemos aplicado un análisis GLMM, con la finalidad de inferir el grado de correlación entre el carácter invasor y ocho atributos de las especies: posibilidad de reproducción asexual, tipo de polinización, modo de dispersión de las diásporas, afinidad por substratos húmedos, tamaño de las diásporas, afinidad por hábitats alterados, tolerancia a la salinidad y longevidad. También se analizan las diferencias que existen entre la flora alóctona total de estas seis zonas del Mundo con respecto a los ocho atributos considerados. Cuando se ha eliminado el sesgo que puedan producir

\footnotetext{
* Gerencia Territorial del Catastro. C/ Ildefonso Rodríguez 1. E-40001 Segovia. E-mail: mario.sanz@segovia.catastro.meh.es

** Área de Ingeniería Cartográfica, Geodésica y Fotogrametría. Escuela Superior y Técnica de Ingeniería Agraria. Universidad de León. Avda. Portugal 41. E-24071 León. E-mail: francisco@agrotecnos.es

*** Departamento de Ingeniería de Diseño y Fabricación. Escuela Politécnica Superior. Universidad de Zaragoza. Carretera de Cuarte s/n. E-22071 Huesca. E-mail: serreta@unizar.es

**** Departamento de Botánica. Universidad de Salamanca. Avda. Licenciado Méndez Nieto s/n, E-37007 Salamanca. E-mail: 1pgavilan@usal.es
} 
los parentescos filogenéticos (efecto taxonómico debido a que determinadas familias aportan mayor número de especies invasoras que comparten los mismos atributos), solamente el modo de dispersión de las diásporas y la afinidad por hábitats alterados parecen estar significativamente correlacionados con el carácter invasor. Si no se tiene en cuenta este efecto, también aparece significativamente correlacionada la tolerancia a la salinidad. A pesar de tratarse de regiones con importantes analogías climáticas, no parece existir un patrón común claro en los atributos de sus respectivas floras alóctonas, siendo éstos dependientes en gran medida de las condiciones locales.

Palabras clave: invasiones biológicas, flora alóctona, zonas áridas.

\section{INTRODUCTION}

Biological invasions currently constitute one of the most important and striking aspects of global environmental change (THUILLER \& al., 2007; ViLÀ \& al., 2006; WitTEMBERG \& COCK, 2001). The consequences of these invasions are felt in many ways. For example, their effects are seen in the progressive loss of biodiversity, the alteration of biogeochemical cycles, the negative interference with certain human activities and interests, and, in short, in the homogenization of Earth's biota (ATKINSON \& CAMERON, 1993). Future global biodiversity scenarios highlight potentially dramatic increases in biological invasions in ecosystems (SALA \& al., 2000). Once an invasive alien species is established in a territory and the process of invasion has been triggered, the measures needed to control or eradicate it are very expensive and not always effective (Pimentel \& al., 2001). These measures can also cause collateral damage in the environment. For these reasons, preventative action is more useful. Consequently, those studies which are designed to discover the complex mechanisms and patterns which bring about and favour invasion processes can produce predicative models. These models then enable us to identify and evaluate situations where there is a risk.

Two approaches to the study of the phenomenon are (1) the identification of the attributes of the species which enable their success in the process of invasion (invasiveness), and (2) the analysis of the conditions of the habitats that make them more vulnerable to invasion by alien plants (invasibility). Environments and regions with extreme climatic conditions and little human influence seem to be those which have less capacity to receive alien species (SANZ ELORZA
\& al., 2006; GASSÓ \& al, 2009). Mountainous areas, the Polar regions, the cold continental steppes and desert and arid areas are examples of these cases. In contrast, those coastal regions which are in mid-latitude countries and which have a high population density are those with the highest numbers of alien flora, both total and invasory (SoBRINo \& al., 2002). In the case of the arid regions, the study of the phenomenon is especially interesting for various reasons. Although these regions do not have lush vegetation, they do amass a rich flora with numerous endemic species adapted to survive in very concrete and hostile environments. Examples of such areas would be places with scarce and unevenly spread rainfall, areas with high temperatures or wide fluctuations in temperature, or regions with very low relative humidity or drying winds. Other examples would be regions with intense rates of sunshine, severe night radiation frosts, high evapotranspiration values or saline ground. These factors cause species to develop highly specialized adaptations. Such mechanisms could include a reduction in the transpiration surface, a shortening of life cycles, the development of tissues to store water or CAM and C-4 metabolisms. The phenomenon of biological invasions in arid zones has not been widely studied, at least on a global scale, unlike other in habitats and countries where information on the presence and distribution of alien plant species can be found in a variety of published and unpublished accounts and databases (MEYERSON \& MOONEY, 2007). However, if the predictions for the future of the climate come true, the extension and distribution of arid zones in the world are going to undergo changes which will require us to take into account the study of all the phenomena and biological processes which are related to them. 
The objectives of this study are (1) to determine which life-history traits are related to the invasiveness of alien plants in arid zones; (2) to clarify the differences in the characteristics of the alien flora in several representative arid regions of the world; and (3) to help develop explicit invasion risk protocols for these zones.

\section{MATERIAL AND METHODS}

In order to carry out the study, we have chosen six representative arid zones from around the world. These are the Mojave and Sonoran Deserts in North America, the Atacama and Peruvian Deserts in South America, the Sahara in the north of Africa and the regions of Tabernas y Monegros
(Spain) in southeast Europe (Figure 1). The Mojave Desert stretches through southwest California. Its climate is characterised by seasonal and daily temperature fluctuations and, on occasions, it suffers from long periods of frost. It includes extremely arid areas, like Death Valley, with average annual mean precipitation of less than 50 $\mathrm{mm}$. The Sonoran Desert extends from the south of California to the south of the Mojave Desert, continuing through southwest Arizona and the northwest of Mexico. Its pattern of temperatures is less cold, although records show an average absolute minimum temperature of $-9.5{ }^{\circ} \mathrm{C}$ (Aguajita/Quitobaquito) and an average absolute maximum of $48.9^{\circ} \mathrm{C}$ (Sierra del Rosario). The annual mean precipitation ranges from $40.22 \mathrm{~mm}$ in El Riito to $267.0 \mathrm{~mm}$ in Aguajita/Quitobaquito

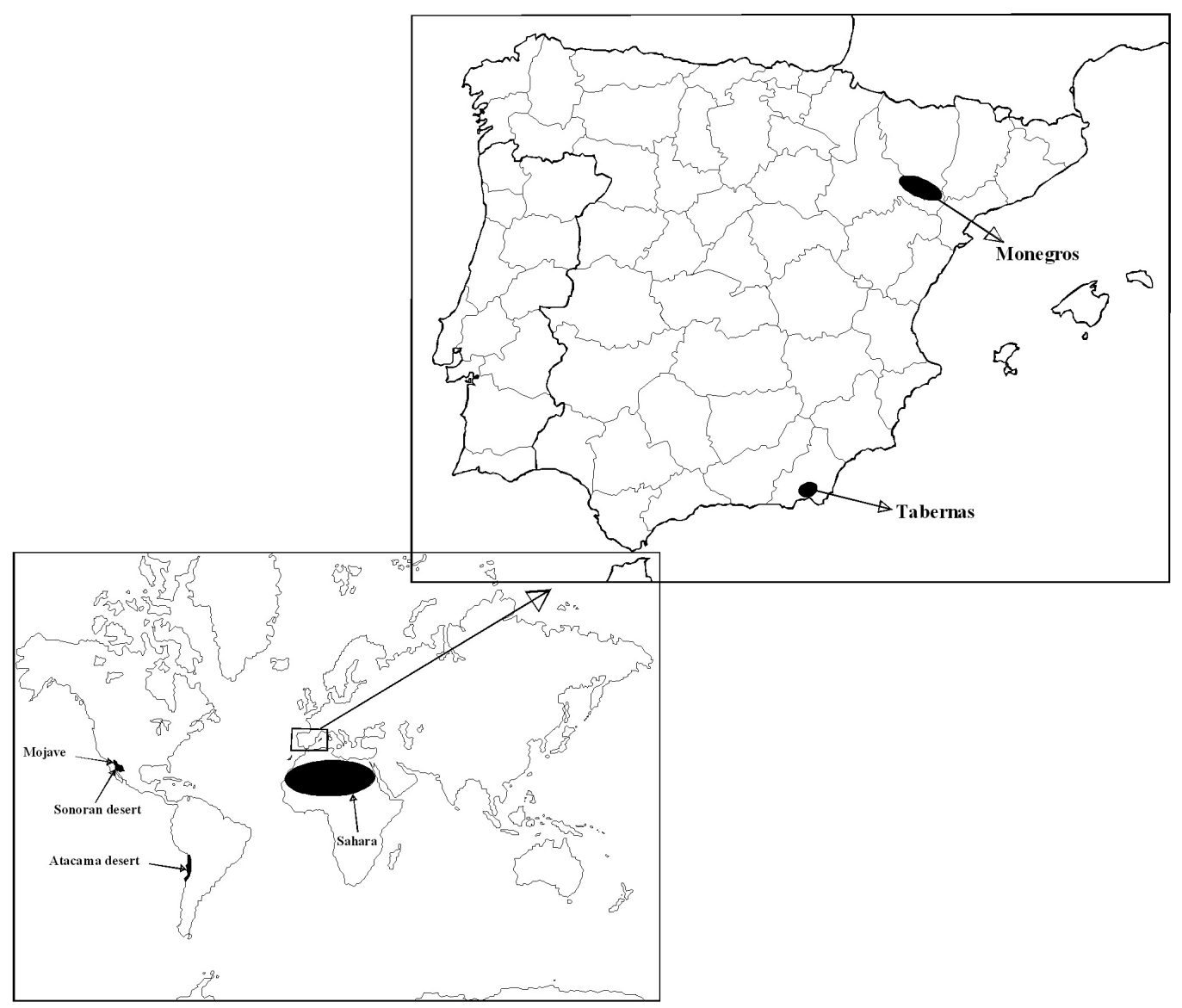

Figura 1.- Geographical location of the six arid areas studied. 
(Felger, 2000). The Atacama and Peruvian Deserts include some of the driest places on earth, with practically no rainfall, (less than $1 \mathrm{~mm}$ of average annual rainfall in Arica and Iquique), although at their southern limit (Copiapó) there was $64 \mathrm{~mm}$ of annual mean precipitation (MCGINNIES, 1977). The Sahara is the largest desert in the world. It extends from the Atlantic coast of Africa to the Red Sea. It also includes some of the warmest and driest areas in the world. For example, the Great Tanezrouft has an annual mean precipitation of less than $25 \mathrm{~mm}$ and in El Azizia, in Libya, the highest temperature in the world was recorded $\left(58^{\circ} \mathrm{C}\right.$ in the shade). The Tabernas Desert extends through southeast Spain and covers an area of approximately $360 \mathrm{~km}^{2}$. The annual mean precipitation of most of this area ranges from 180 to $250 \mathrm{~mm}$. The maximum temperatures in the hottest months are above $34^{\circ} \mathrm{C}$ and the minimum temperatures in the coldest months are rather mild with only light frosts. The Monegros Desert is a wide continental steppe area that stretches through the north-eastern part of the Iberian Peninsula in Spain, and covers an area of approximately $2,760 \mathrm{~km}^{2}$. Its climate has some extreme temperatures, with maximum summer temperatures that can reach over $40{ }^{\circ} \mathrm{C}$, and minimum winter temperatures that can be as low as $-12{ }^{\circ} \mathrm{C}$. The annual mean precipitation ranges from 300 to $420 \mathrm{~mm}$, although it is very irregularly spread out over the year.

For each area, we have catalogued the alien vascular flora from the following sources: Mojave (BALDWIN \& al., 2002); Sonoran Desert (Felger, 2000; NABHAN \& al., 2002); Sahara (OzENDA, 1991; Quezel \& SANTA, 1962-1963; MAIRE, 1952-1980); Atacama and Peruvian Deserts (Dillon, 2005); Tabernas (KUNKEL, 1988; SAGREdo, 1987; Dana \& al., 2001); Monegros (Molero \& Blanché, 1998; SANZ Elorza, 2006). We have only taken into account naturalized species, according to the criteria of RICHARDSON \& al. (2000), and have not included casuals or sub-spontaneous species. From the information obtained from the cited sources, we considered that a species shows an invasive characteristic when in at least one of the regions studied there are reasons to think that it fulfils the criteria esta- blished by RichARDSON \& al. (2000) and PYŠEK \& al. (2004) relating to the term invader when applied to vascular plants. In short, the aforementioned authors define an invasive plant as an alien species with self-sustainable populations without direct human intervention that produces offspring at considerable distances from the parent plants, and thus has the potential to spread over large areas. Invasiveness is quantified as a continuous numeric variable (number of regions where it shows an invasive characteristic).

Once the list of alien naturalized plants in the six arid zones studied had been compiled, a database was created with eight biological and ecological plant traits, according to the scientific literature (PYŠEK \& al., 1995; GOODWIN \& al., 1999; LlORET \& al., 2003; SANZ ElORZA \& al., 2006; GASSÓ \& al., 2009). These were the traits that could potentially be related to the invasion success of alien species. These variables are clonality (yes, no), pollination model (wind, insects, water), dispersal syndrome (anemochorous, hydrochorous, zoochorous and others that include barochorous, balistochorous, etc.), linking to moist soils (yes, no), seed size (very small if $<1$ $\mathrm{mm}$, small between 1-3 mm, medium between 3$5 \mathrm{~mm}$, large between $5-10 \mathrm{~mm}$ and very large if $>10 \mathrm{~mm}$ ), linking to disturbed habitats (yes, no), salinity tolerance (yes, no) and longevity (annual, perennial). We used a test $\chi^{2}$ in order to determine if significant differences exist between the results obtained in each of the areas.

For statistical analysis, we used Generalized Linear Mixed Models (GLMM) to model the species invasion success (invasiveness) according to the eight predictors previously described. Typical GLM can estimate and test any univariate or multivariate general linear model, including those for multiple regression, analysis of variance or covariance, and other procedures such as discriminant analysis and principal components. The model is:

$$
\mathrm{Y}=\mathrm{XB}+\mathrm{e}
$$

where $\mathbf{Y}$ is a vector or matrix of dependent variables (they should be continuous numeric variables), $\mathbf{X}$ is a vector o matrix of independent variables (they may be either continuous or cate- 
gorical dummy variables, according to the type of model), $\mathbf{B}$ is a vector or matrix of regression coefficients, and e is a vector or matrix of random errors (SEARLE, 1971; Winer, 1971; NETER \& al., 1985; CoHen \& CoHen, 1983).

After the parameters of the model have been estimated, they can be tested by any general linear hypothesis (in our model, life-history traits are related to the invasiveness of alien plants in arid zones) in the following form:

$$
\mathrm{ABC}^{\prime}=\mathrm{D}
$$

where $\mathbf{A}$ is a matrix of linear weights on coefficients across the independent variables (the rows of $\mathbf{B}), \mathrm{C}$ is a matrix of linear weights on the coefficients across dependent variables (the columns of $\mathbf{B}$ ). In our model, $\mathbf{C}$ is an identity matrix. $\mathbf{B}$ is the matrix of regression coefficients of effects, and $\mathbf{D}$ is a null hypothesis matrix (null matrix). However, there is a clear bias as far as both the invasive characteristics of the species and their biological and ecological attributes are concerned. This is due to the phylogenetic relationship, and is defined as taxonomic bias. This causes an erroneous increase in the number of degrees of freedom as each species is used as an independent piece of data (BRÄNDLE \& al., 2003), with the resulting increase of type-I errors. GLMM enables the phylogenetic effect to be mitigated by means of the incorporation of the taxonomic categories, in our case the genus, as nested random factors. This partly controls the probable lack of independence of the values assumed by the variables in species that are phylogenetically close (GASsó \& al., 2009).

\section{RESULTS}

\section{SPECIES APPROACH}

The inventory of the alien flora of the areas studied, extracted from bibliographical sources, lists a total of 347 species although there are notable qualitative and quantitative differences as far as the location of each area is concerned (Table 1).
Accounting for taxonomic relationships, of the eight selected predictors, only two are significantly related to the invasion characteristic (Table $2)$. These are dispersal syndrome and linking to disturbed sites. If taxonomic bias is not considered, the salinity tolerance $(F$-ratio $=9.097 ; p$ value $=0.0027$ ) also appears to be significantly related to the invasion characteristic, as halophyte species are concentrated in a few families and genera. With regard to the dispersal syndrome, the wind and rain can be seen to be the main vectors of invasive alien species (Figure 2). As far as linking to disturbed sites is concerned the invasive species are largely ruderal and nitrophilous (Figure 2).

\section{ALIEN FlORAS OF ARID ZONES}

The analysis of the differences in the percentages of alien species obtained in each area for each of the predictors, with relation to the overall

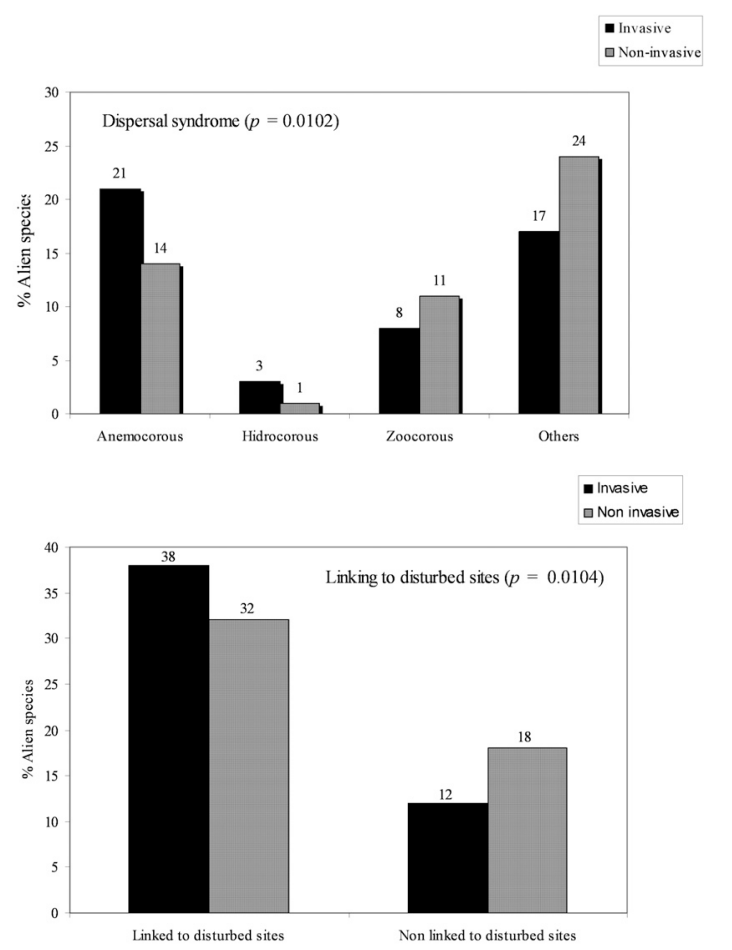

Figura 2. - Characterisation of the alien flora of the arid zones which were studied. Non-significant results have been omitted. 


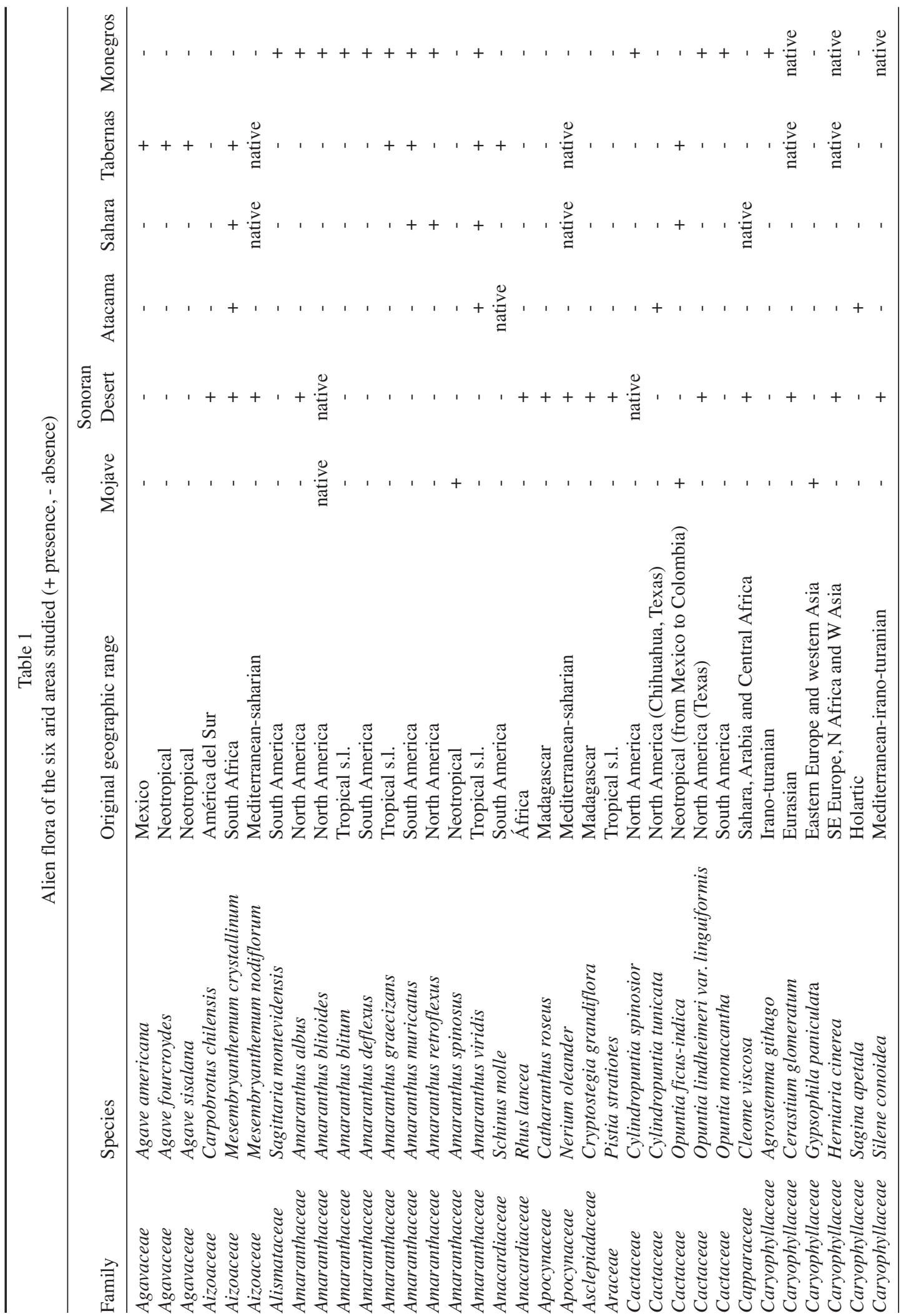




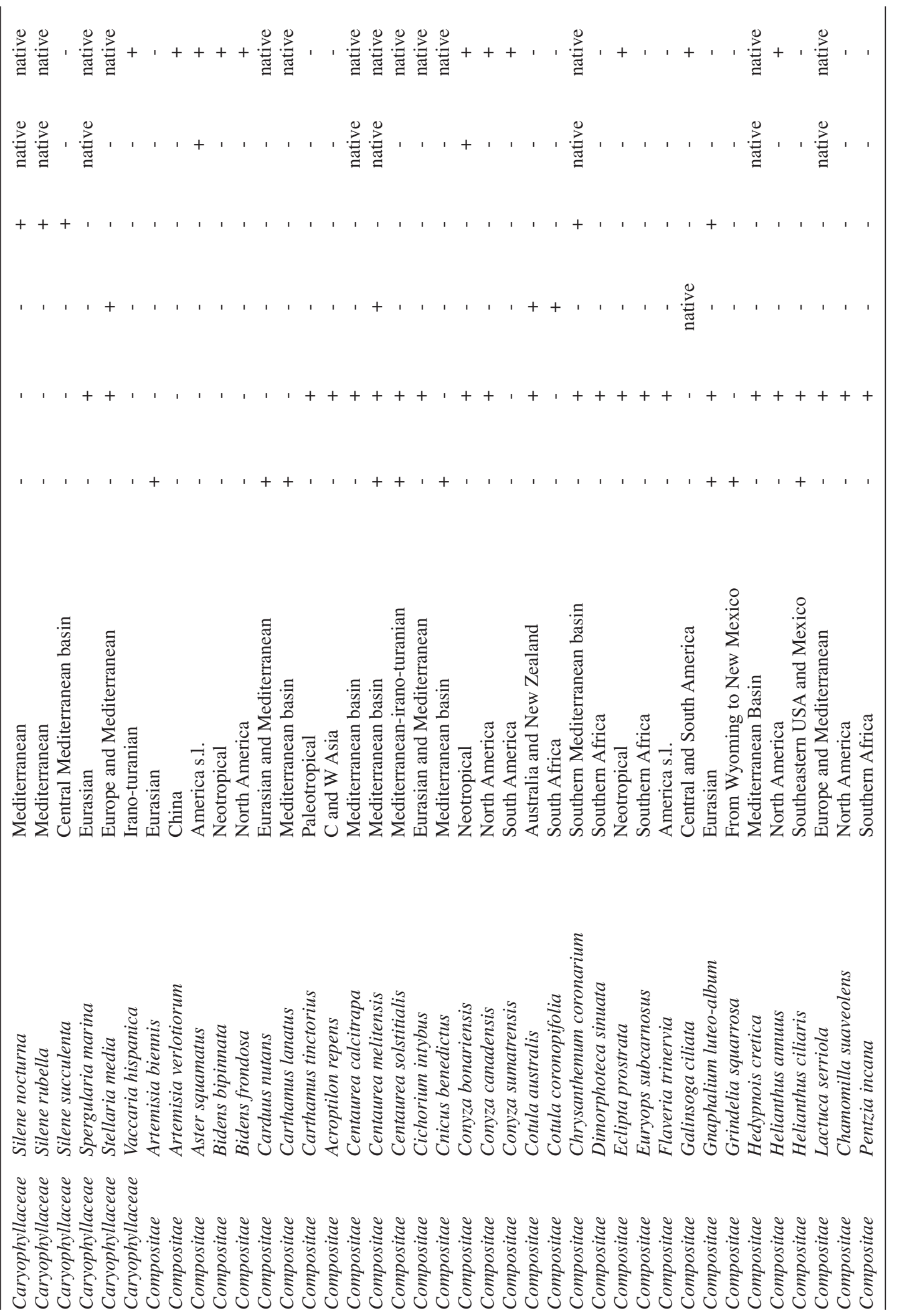




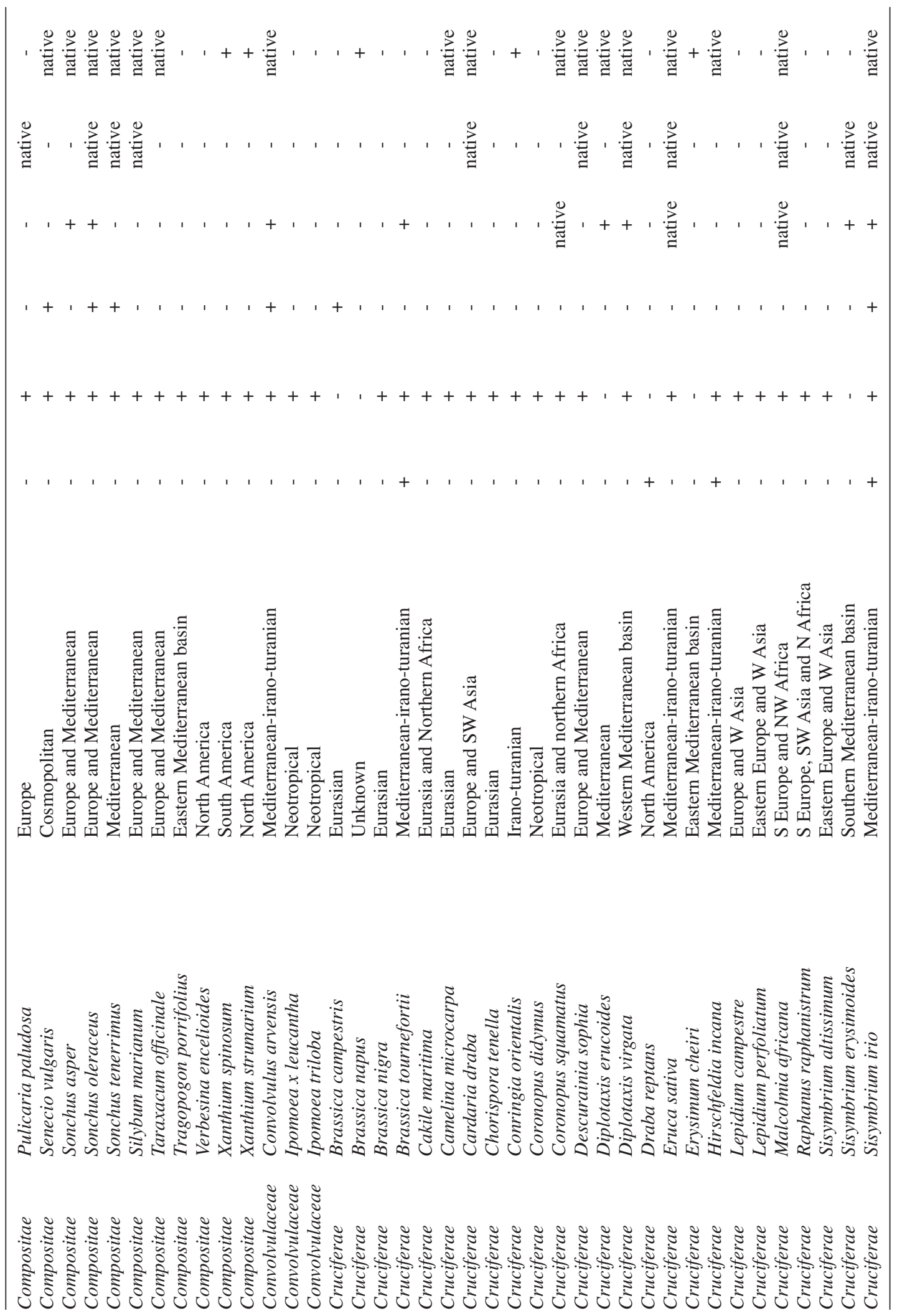




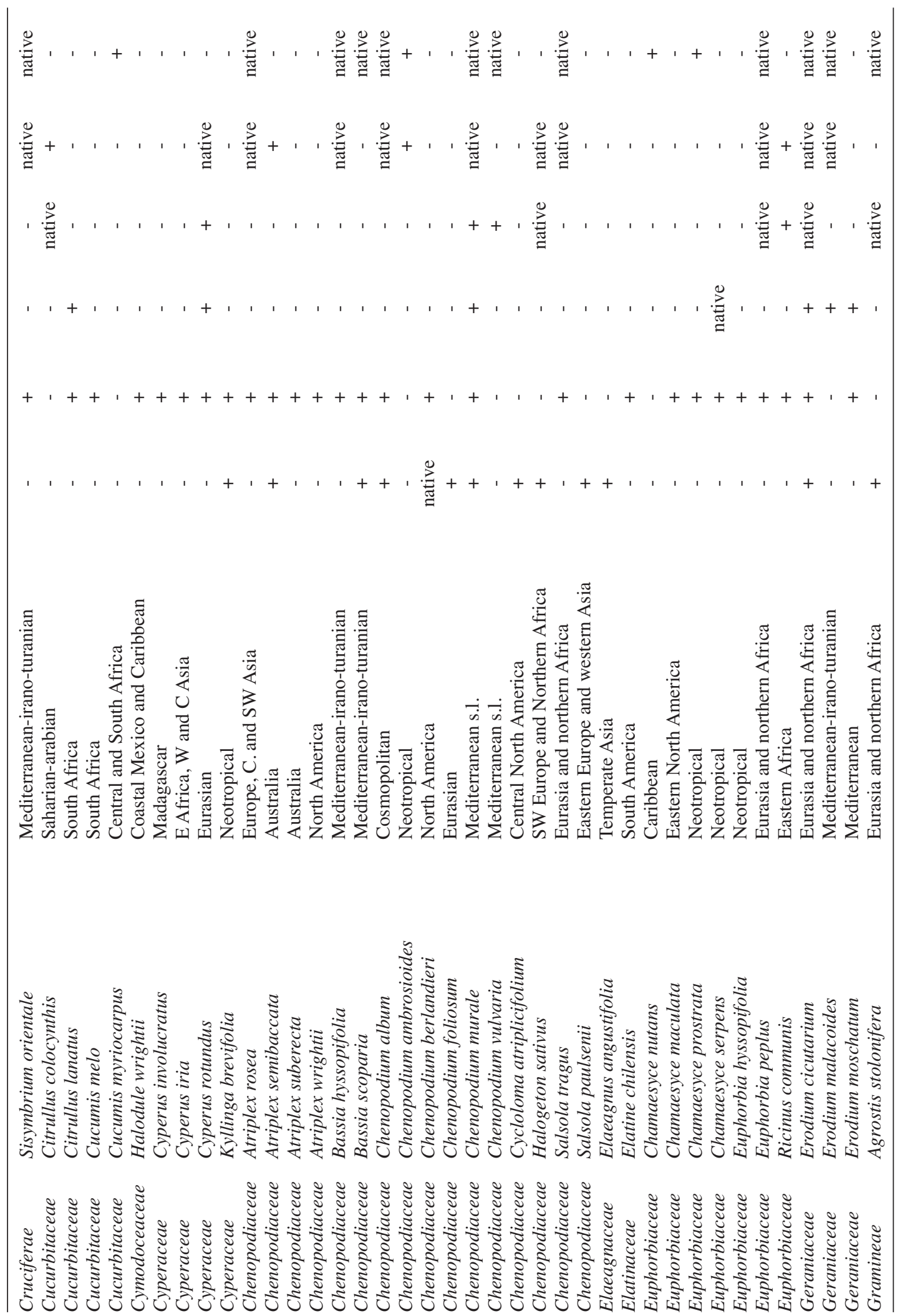




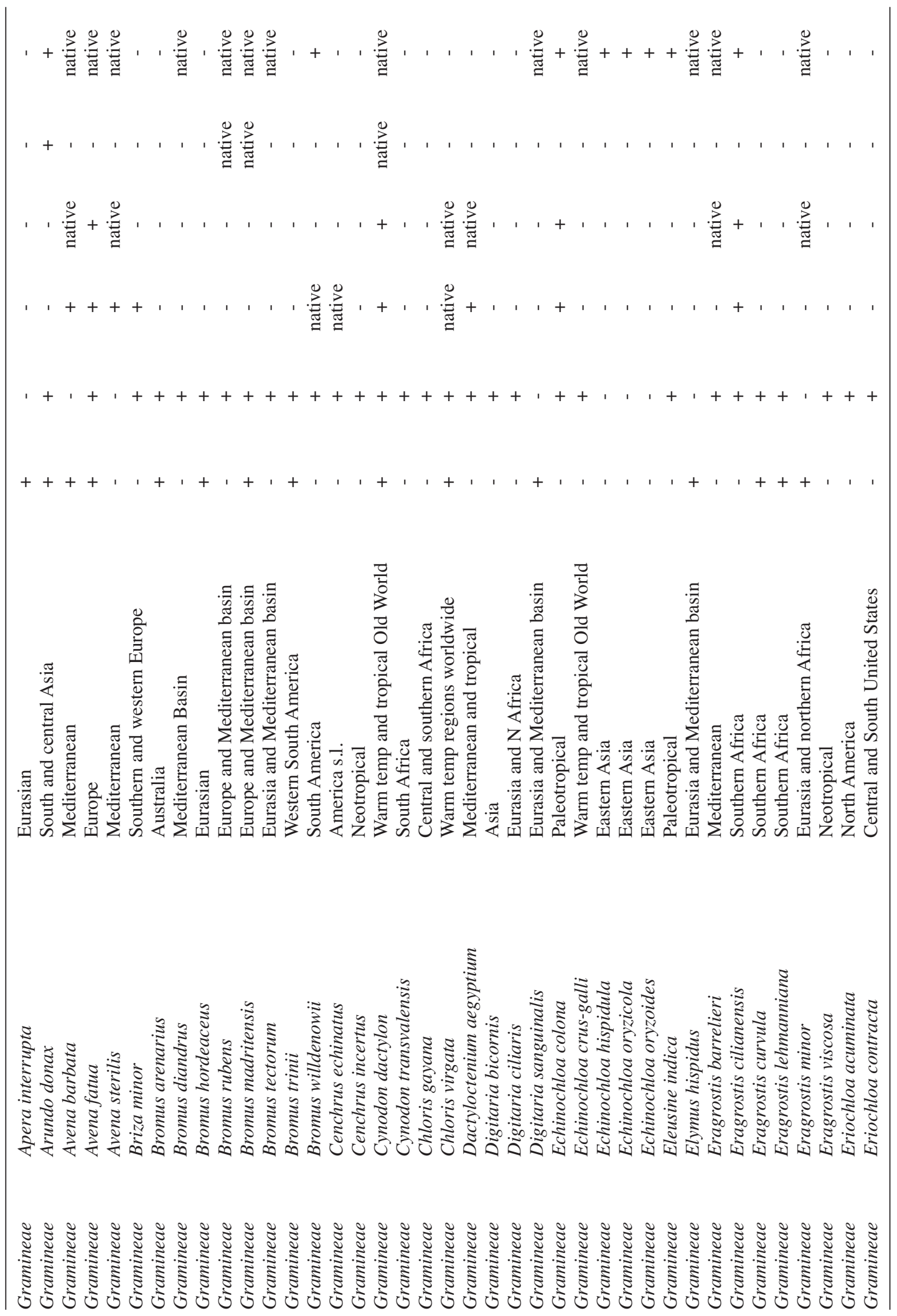




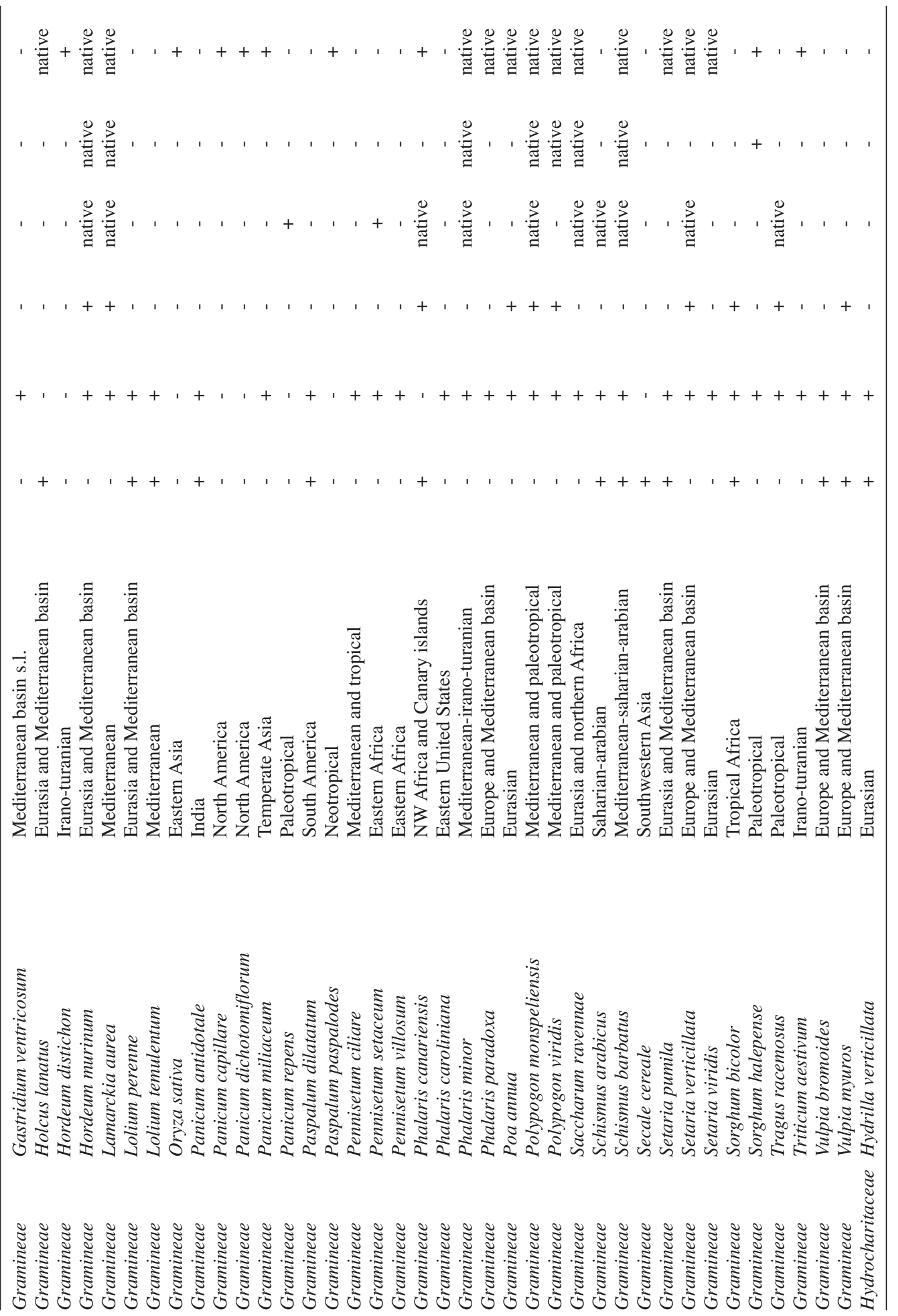




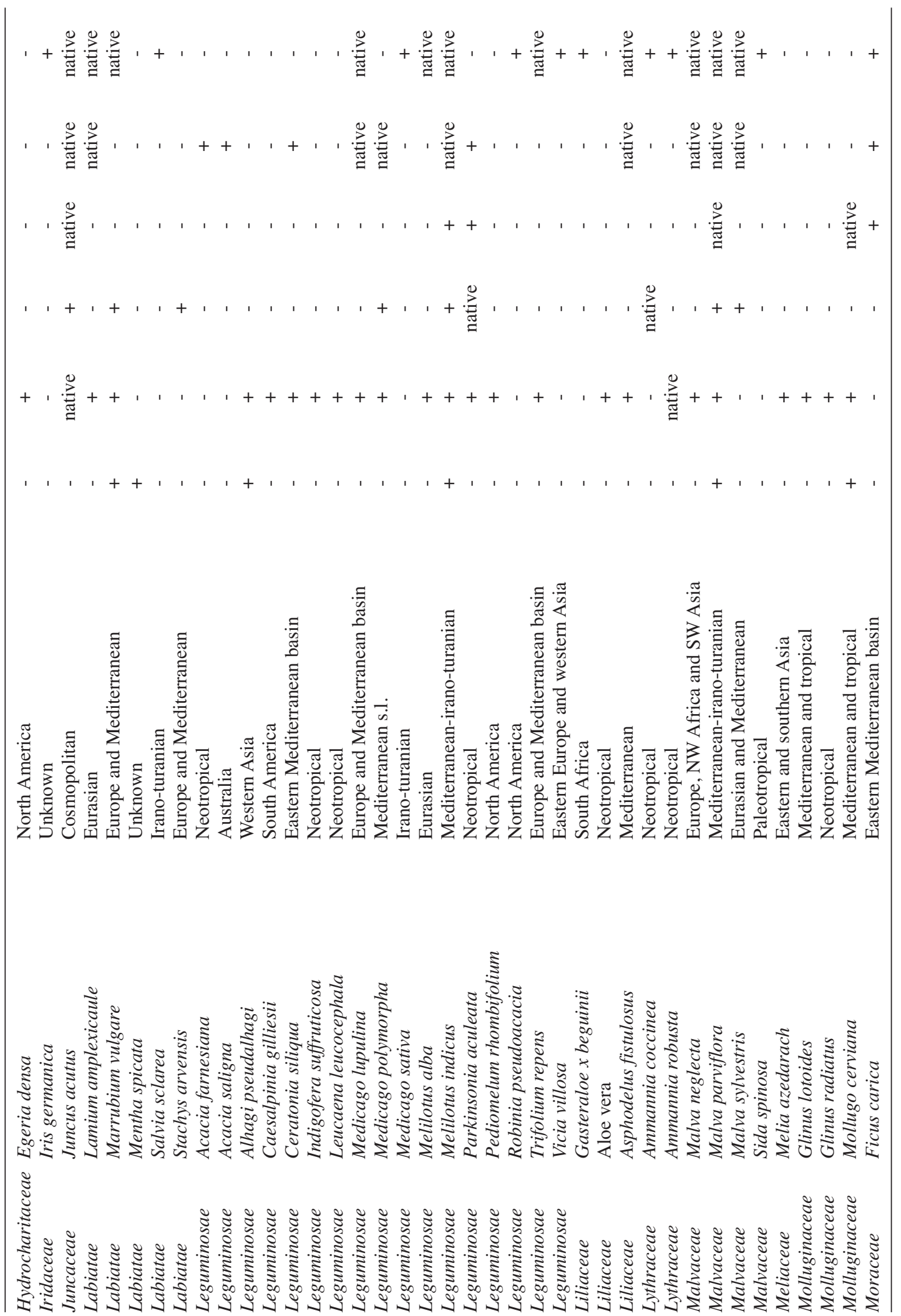




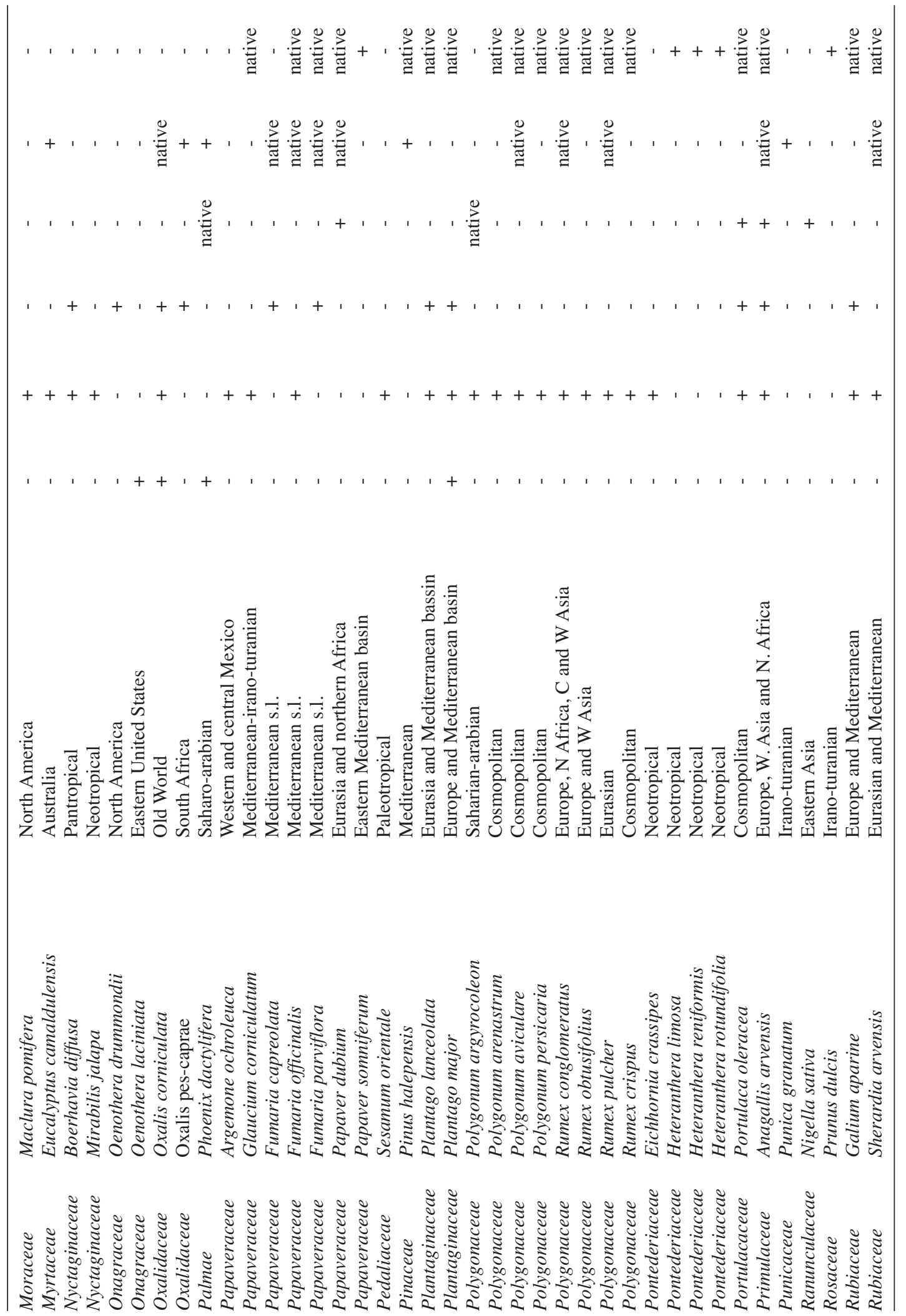




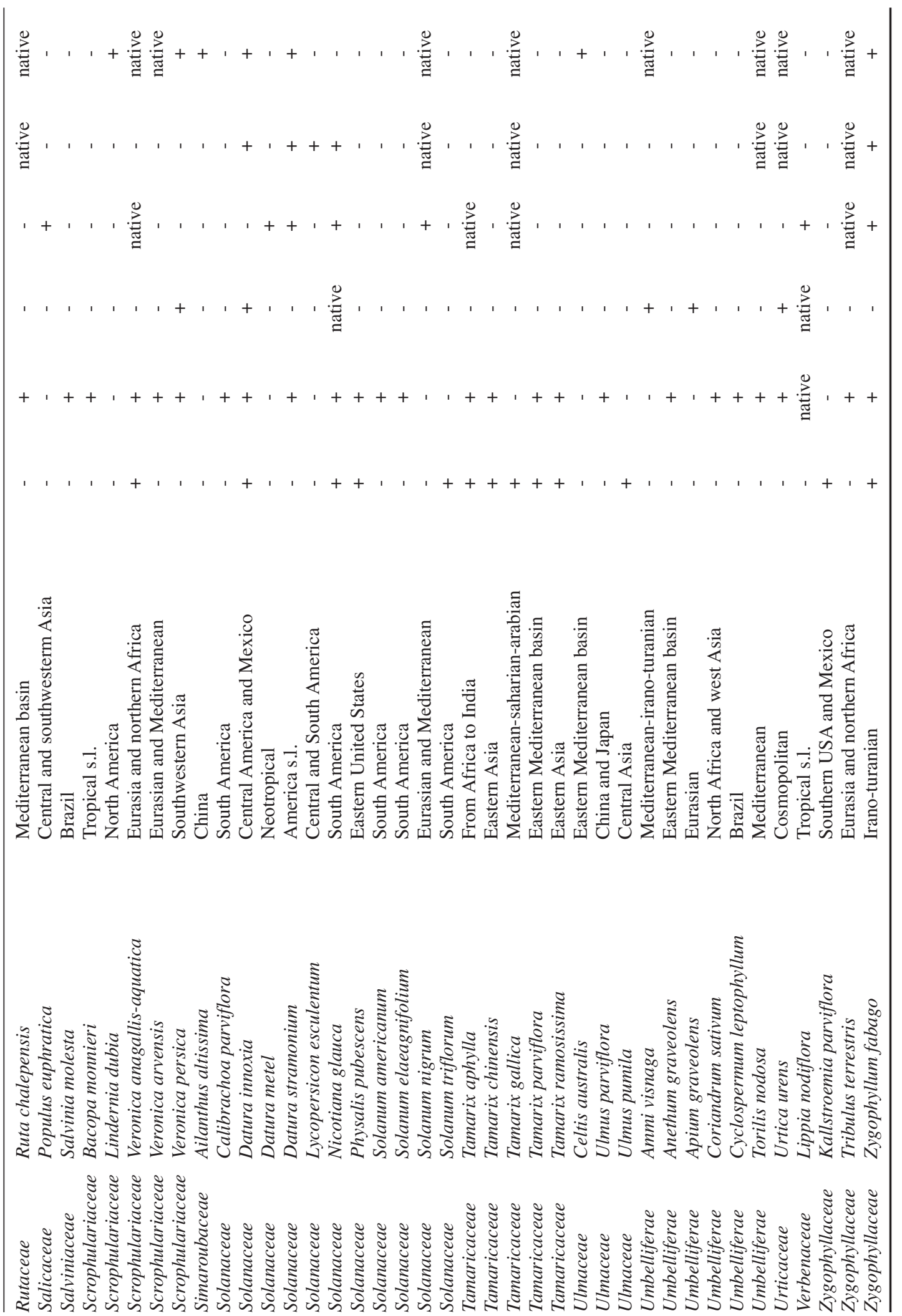


Table 2

Tests of significance for dependent variable (invasiveness) and predictors which are significantly related. Sigma-restricted parameterization. Effective hypothesis decomposition.

\begin{tabular}{lccccc}
\hline & Sum of squares & df & Mean-square & $F$-ratio & $p$-value \\
\hline Intercept & 425.0527 & 1 & 425.0527 & 1736.809 & 0.000000 \\
Dispersal syndrome & 2.8062 & 3 & 0.9354 & 3.822 & 0.010232 \\
Error & 83.9431 & 343 & 0.2447 & & \\
Intercept & 620.3791 & 1 & 620.3791 & 2514.645 & 0.000000 \\
Linking to disturbed sites & 1.6356 & 1 & 1.6356 & 6.630 & 0.010446 \\
Error & 85.1137 & 345 & 0.2467 & & \\
\hline
\end{tabular}

arid areas shows that, in general, the dry areas of the Old World are more distinct than those of the American continent (Table 3).

\section{DISCUSSION AND CONCLUSIONS}

Our approach enables us to identify the factors that favour the invasiveness of introduced species in arid zones. Until now, only a few species attributes have been shown to be significantly related to the invasiveness of alien plants (THOMPSON \& al., 1995; SOBRINO \& al., 2002; LlORET \& al., 2003; SANZ ElORZA \& al., 2006). The two predictors that we have found to be related to the phenomenon in dry areas had already been related to the invasiveness of alien species in other parts of the world, and in other ecological environments. The relation between dispersal syndrome and invasion success of the species dispersed by wind (anemochorous) in the western Mediterranean (GASSó \& al., 2009) has been proved and coincides with what has been observed in dry areas. Nevertheless, in these dry areas, species dispersed by water (hydrochorous) have also shown themselves to be capable of becoming successful invaders. Obviously, in dry areas the environments where hydrochorous species can trigger invasion processes are very limited, therefore resulting in surface extension areas which are not very significant. Moreover, in specific concrete and delimited wetland habitats the application of prevention and control strategies is much more straightforward. On the other hand, species linked to moist soils have not shown themselves to be more efficient invaders in any significant way, although in areas where agriculture with irrigation is important the opposite may be true. This situation occurs in Monegros (Table 3 ), and is the explanation for the different behaviour of this area with respect to the general pattern. Many of the invasive alien species present are weeds of irrigated crops that come from tropical areas (SANZ ElORZA \& al., 2006).

Apart from dispersal syndrome and linking to disturbed sites, the rest of the traits studied have not been found to be related to invasion success. It is striking that characteristics such as seed size, capacity for clonal reproduction, linking to moist soils or longevity do not explain the phenomenon of invasiveness of alien plants in dry areas, as could have at first been assumed. This situation reinforces the theory of the absence of a general pattern of the attributes of invasive species, as these are largely dependent on the type of habitat and the geographical environment in which they are found (THOMPSON \& al., 1995).

In the comparison of the alien flora of the six areas studied (Table 3), it can be seen that the Tabernas Desert differs significantly in all the attributes with respect to the global pattern of the arid areas. Monegros is only $700 \mathrm{~km}$ away, and is only significantly different with respect to linking to moist soils due to the importance of irrigated agriculture. The attributes of the alien flora of Monegros seem to bear a closer resemblance to the alien flora of the deserts of North America, where the arid conditions are more similar and not as extreme as those of the Sahara or the Atacama and Peruvian Deserts. These last two, which are the most genuine deserts, show significant differences in biological types, with a gre- 
Table 3

Percentages of the number of alien species present in each area studied and in all the areas as a whole, for each of the predictors taken into account. The biological types are: $\mathrm{C}$ chamaephyte, $\mathrm{G}$ geophyte, $\mathrm{H}$ hemicryptophyte, Hy hydrophyte, $\mathrm{P}$ phanerophyte, T therophyte. The pollination modes are: An anemophilous, En entomophilous,

Hi hydrophilous. The dispersal syndromes are: An wind (anemochorous), Hi water (hydrochorous),

Zoo animals (zoochorous), others (including barochorous, balistochorous, etc.). The test $\chi^{2}$ was used to determine if significant differences exist between the results obtained in each of the areas.

\begin{tabular}{|c|c|c|c|c|c|c|c|c|}
\hline & & & Sonoran & & & & & \\
\hline & & Mojave & Desert & Atacama & Sahara & Tabernas & Monegros & Global \\
\hline Biological type & $\mathrm{C}$ & 3 & 3 & 2 & 0 & 9 & 3 & 3 \\
\hline & G & 4 & 4 & 7 & 5 & 6 & 4 & 4 \\
\hline & $\mathrm{H}$ & 18 & 15 & 12 & 19 & 13 & 11 & 45 \\
\hline & Hy & 3 & 3 & 7 & 10 & 0 & 7 & 3 \\
\hline & $\mathrm{P}$ & 15 & 13 & 0 & 0 & 38 & 10 & 13 \\
\hline & $\mathrm{T}$ & 59 & 62 & 72 & 67 & 34 & 65 & 62 \\
\hline & $\chi^{2}$ & 1.0528 & 0.0931 & 23.1296 & 34.0532 & - & 7.2375 & - \\
\hline & p-value & 0.9582 & 0.9998 & 0.0003 & $<0.0001$ & $<0.0001$ & 0.2036 & - \\
\hline Clonality & no & 79 & 82 & 85 & 74 & 66 & 79 & 80 \\
\hline & yes & 21 & 18 & 15 & 26 & 34 & 21 & 20 \\
\hline & $\chi^{2}$ & 0.0625 & 0.2500 & 1.5625 & 2.2500 & 12.2500 & 0.0625 & - \\
\hline & p-value & 0.8026 & 0.6171 & 0.2113 & 0.1336 & 0.0005 & 0.8026 & - \\
\hline Linked to moist soils & no & 51 & 54 & 48 & 48 & 62 & 44 & 52 \\
\hline & yes & 49 & 46 & 52 & 52 & 38 & 66 & 48 \\
\hline & $\chi^{2}$ & 0.0401 & 0.1603 & 0.6410 & 0.6410 & 4.0064 & 7.9807 & - \\
\hline & p-value & 0.8414 & 0.6889 & 0.4234 & 0.4234 & 0.0453 & 0.0047 & - \\
\hline Pollination mode & An & 71 & 69 & 77 & 67 & 47 & 68 & 66 \\
\hline & En & 28 & 30 & 23 & 33 & 53 & 32 & 33 \\
\hline & $\mathrm{Hi}$ & 1 & 1 & 0 & 0 & 0 & 0 & 1 \\
\hline & $\chi^{2}$ & 1.1363 & 0.4091 & 5.8636 & 1.0152 & 18.5909 & 1.0909 & - \\
\hline & p-value & 0.5665 & 0.8150 & 0.0533 & 0.6019 & $<0.0001$ & 0.5796 & - \\
\hline Dispersal syndrome & An & 50 & 38 & 34 & 29 & 19 & 28 & 35 \\
\hline & $\mathrm{Hi}$ & 1 & 4 & 2 & 5 & 0 & 10 & 5 \\
\hline & Zoo & 13 & 19 & 21 & 12 & 25 & 21 & 19 \\
\hline & others & 36 & 38 & 43 & 55 & 56 & 42 & 41 \\
\hline & $\chi^{2}$ & 12.1331 & 0.6766 & 2.1366 & 8.3881 & 19.6968 & 6.6349 & - \\
\hline & $p$-value & 0.0069 & 0.8787 & 0.5445 & 0.0386 & 0.0002 & 0.0845 & - \\
\hline Seed size & VS & 25 & 20 & 18 & 31 & 19 & 17 & 20 \\
\hline & $\mathrm{S}$ & 39 & 44 & 51 & 50 & 28 & 43 & 44 \\
\hline & M & 14 & 16 & 10 & 10 & 19 & 26 & 15 \\
\hline & $\mathrm{L}$ & 14 & 14 & 13 & 5 & 28 & 10 & 13 \\
\hline & VL & 9 & 7 & 8 & 5 & 6 & 4 & 7 \\
\hline & $\chi^{2}$ & 2.5332 & 0.1436 & 3.1232 & 14.0294 & 24.3854 & 10.5174 & - \\
\hline & $p$-value & 0.6387 & 0.9975 & 0.5374 & 0.0072 & $<0.0001$ & 0.0326 & - \\
\hline Linked to distubed sites & no & 30 & 28 & 21 & 26 & 47 & 21 & 29 \\
\hline & yes & 70 & 72 & 79 & 76 & 53 & 79 & 71 \\
\hline & $\chi^{2}$ & 0.0456 & 0.0455 & 3.1033 & 0.6625 & 15.7358 & 3.1083 & - \\
\hline & p-value & 0.8256 & 0.8257 & 0.0779 & 0.4157 & $<0.0001$ & 0.0779 & - \\
\hline Salinity tolerance & no & 84 & 91 & 92 & 88 & 84 & 94 & 91 \\
\hline & yes & 16 & 9 & 8 & 12 & 16 & 6 & 9 \\
\hline & $\chi^{2}$ & 5.9829 & - & 0.1221 & 1.0989 & 5.9829 & 1.0989 & - \\
\hline & $p$-value & 0.0144 & 1 & 0.7268 & 0.2945 & 0.0144 & 0.2945 & - \\
\hline Longevity & annual & 59 & 64 & 72 & 69 & 38 & 69 & 63 \\
\hline & perenne & 41 & 36 & 28 & 31 & 62 & 31 & 37 \\
\hline & $\chi^{2}$ & 0.6864 & 0.0429 & 3.4749 & 1.5444 & - & 1.5444 & - \\
\hline & $p$-value & 0.4074 & 0.8359 & 0.0623 & 0.2139 & $<0.0001$ & 0.2139 & - \\
\hline
\end{tabular}


ater presence of therophytes and an almost total absence of phanerophytes and chamaephytes. This is easily explained if we consider the conditions of extreme dryness of these deserts and the absence of wetlands and fluvial courses that could mitigate the situation on a local scale. In these conditions, the therophytes are the best adapted to survive, as they take advantage of any sign of temporary humidity that allows them to complete their cycle quickly. In the alien flora of the Sahara, significant differences can be observed in the global pattern of seed size, as the species with small seeds acquire greater quantitative importance. Many of the alien species in the Sahara are, in fact, therophytes of Mediterranean origin with small seed size. The Sonoran Desert does not significantly differ from the general pattern in any of the traits we considered. This is partly because this zone had the greatest number of alien species of all the arid zones in the study. This could be because there are more environments which are altered by human influence, as there are several cities with large populations in this desert, unlike in the other five areas. In the Mojave Desert, the significant difference which can be seen with respect to dispersal syndrome is worth noting. This is caused by the greater fre- quency of alien species with anemochorous dispersion.

We can conclude that in dry areas, dispersal syndrome is a determining factor of invasiveness. This agrees with the descriptions in the classic literature about the ecology of invasive alien plants (RichaRdSON \& al., 2000; Kolar \& LOdGe, 2001; PRINZING \& al., 2002). Moreover, the harsh environmental conditions of the arid zones create an ecological barrier that is difficult for alien plants to overcome, as they tend to be concentrated in environments which are altered by human activity. For this reason, the best preventative measure against invasive alien plants has been shown to be making the preservation of the habitats of arid zones a priority in nature conservation policies. The differences in the attributes of the alien species in the six areas studied show that, in spite of the fact that they all have an arid climate in common, there are more subtle environmental factors in play which cause deviations with respect to a hypothetical general situation. Therefore, the theory of the absence of a general pattern in the attributes of alien species is proved to be true. These species are largely dependent on local conditions, even in the case of regions with major climatic analogies.

\section{REFERENCIAS}

Atkinson, I.A.E. \& Cameron, E.K. -2003- Human influence on the terrestrial biota and biotic communities of New Zealand - Trends Ecol. Evol. 8: 447-451.

Baldwin, B.G., Boyd, S., Ertter, B.J., Patterson, R.W., Rosatti, T.J. \& Wilken, D.H. - 2002- The Jepson Desert Manual. Vascular plants of southeastern California Univ. California Press. Berkeley \& Los Angeles.

Brändle, M., Stadler, J., Klotz, S. \& Brandl., R. -2003Distributional Range size of weedy plant species is correlated to germination patterns - Ecology 84: 136-144.

Cohen, J. \& Cohen, P. - 1983 - Applied multiple regression/correlation analysis for the behavioral sciences. 2nd ed. - Lawrence Erlbaum, Hillsdale, N.J.

Dana, E., Cerrillo, M.I., Sanz-Elorza, M., Sobrino, E. \& Mota, J.F. - 2001- Contribución al conocimiento de las xenófitas en España: Catálogo provisional de la flora alóctona de Almería - Acta Bot. Malacitana 26: 264-276.

Dillon, M.O. -2005- Checklist of the Vascular Flora of the Peruvian and Atacama Deserts - http://www.sacha.org/envir/deserts/flora/taxa
Felger, R.S. - 2000 - Flora of the Gran Desierto and Río Colorado of northwestern Mexico - The Univ. Arizona Press. Tucson, Arizona.

Gassó, N., Sol, D., Pino, J., Dana, E.D., Lloret, F., SanzElorza, M., Sobrino, E. \& Vilà, M. -2009- Exploring species attributes and site characteristics to assess plant invaders success - Div. Distr. 15: 50-58.

Goodwin, B.J., McAllister, A.J. \& Fahrig, L. - 1999- Predicting invasiveness of plant species based on biological information - Cons. Biol. 13: 422-426.

Kunkel, G. - 1988 - Flórula del desierto almeriense Inst. Estud. Almerienses, Almería.

Kolar, C.S. \& Lodge, D.M. - 2001 - Progress in invasion biology: predicting invaders. - Trends Ecol.Evol. 16: 199-204.

Lloret, F., Médail, F., Brundu, G. \& Hulme, P.E. -2003Local and regional abundance of exotic plant species on Mediterranean islands: are species traits important? Global Ecol. Biogeogr. 12: 1-9.

McGinnies, W.G., Goldman, B.J. \& Paylore, P. -1977— Deserts of the World - Univ. Arizona Press, Third printing. Tucson, Arizona, USA. 
Maire, R. -1952-1980 - Flore de l'Afrique du Nord. Volumes I-XXV - Paul Lechevalier Éditeur, Paris, France.

Meyerson, L.A. \& Mooney, H.A. - 2007- Invasive alien species in an era of globalization. - Front. Ecol. Environ. 5: 199-208.

Molero, J. \& Blanché, C. - 1998- Lista florística de los Monegros - In: Pedrocchi, C. (Ed.). Ecología de los Monegros. Pp. 373-385. Inst. Estud. Altoaragoneses. Huesca.

Nabhan, G.P, West, P., Felger, R.S., O'Brien, M., O'Brien, J., Van Devender, T.R., Guerrero, A.L., McLaughlin, S.P., Jenkins, P. \& Stromberg, J.C. -2002 - Naturalized exotic species in the Sonoran Region. Flora - In: Tellman, B. (Ed.). Invasive Exotic Species in the Sonoran Region. Pp. 346-355. Univ. Arizona Press. Tucson, Arizona.

Neter, J., Wasseman, W. \& Kutner, M. -1985 - Applied linear statistical models. 2nd ed. - Richard E. Irwin, Inc. Homewood, Illinois.

Prinzing, A., Drka, W., Klotz, S. \& Brandl, R. -2002Which species become aliens. - Evol. Ecol. Res. 4: 385-405.

Ozenda, P. - 1991 - Flore et végétation du Sahara. CNRS Editons. 10th ed., Paris, France.

Pimentel, D., McNair, S., Janecka, J., Wigtman, J., Simmonds, C., O'Connell, C., Wong, E., Russel, L., Zern, J., Aquino, T. \& Tsomondo, T. - 2001- Economic and environmental threats of alien plant, animal, and microbe invasions. - Agric. Ecosyst. Env. 84: 1-20.

Pyšek, P., Prach, K. \& Smilauer, P. - 1995- Relating invasion success to plant traits: an análisis of the czech alien flora - In: Pyšek, P., Prach, K., Rejmánek, M. Wade, M. (Eds.). Plant invasions: general aspects and special problems. Pp. 39-60. Acad. Publ. Ámsterdam.

Pyšek, P., Richardson, D.M., Rejmánek, M., Webster, G.L., Williamson, M. \& Kirschner, J. -2004- Alien plants in checklists and floras: towards better communication between taxonomists and ecologists - Taxon 53(1): 131-143.

Quezel, P. \& Santa., S. -1962-1963 - Nouvelle flore de l'Algerie et des régions désertiques meridionales - Ed. Centr. Nat. Rech. Sci. Paris.

Recibido: 22 febrero 2009

Aceptado: 25 noviembre 2010
Richardson, D.M., Pyšek, P., Rejmánek, M., Barbour, M.G., Panetta, F.D. \& West, C.J. - 2000 - Naturalization and invasion of alien plants: concepts and definitions - Div. Distr. 6: 93-107.

Sagredo, R. -1987- Flora de Almería - Dip. Prov. Almería. Almería. Spain.

Sala, O.E., Stuart, F., Armesto, J.J., Berlow, E., Bloomfield, J., Davis, F., Dirzo, R., Froydis, I., Huber-Sanwald, E., Huenneke, L.F., Jackson, R., Kinzig, A., Leemans, R., Lodge, D., Malcolm, J., Mooney, H.A., Oesterheld, M., Poff, L., Styles, M.T., Walker, B.H., Walker, M. \& Wall, D. $-2000-$ Global biodiversity scenarios for the year 2100 - Science 287: 1770-1774.

Sanz Elorza, M. - 2006 - La flora alóctona del Altoaragón. Flora analítica de xenófitas de la provincia de Huesca Gihemar S.A. Segovia.

Sanz Elorza, M., Dana, E.D. \& Sobrino, E. - 2006 - Invasibility of an inland area in NE Spain by alien plants Acta Oecol. 29: 114-122.

Searle, S.R. - 1971 - Linear models - John Wiley \& Sons. New York. USA.

Sobrino, E., Sanz Elorza, M., Dana, E.D. \& González, A. -2002 - Invasibility of a coastal strip in NE Spain by alien plants - J. Veg. Sci. 13: 585-594.

Thuiller, W., Richardson \& D.M., Midgley, G.F. -2007Will climate change promote alien plant invasions? In: Nentwig, W. (Ed.). Biological invasions, Ecological studies. Pp. 197-211. Springer-Verlag, Berlin.

Thompson, K., Hodgson, J.G. \& Rich, T.C.G. -1995Native and alien invasive plants: more of the same? Ecography 18: 390-402.

Vilá, M., Corbin, J.D., Dukes, J.S., Pino, J. \& Smith, S.D. 2006 - Linking plant invasions to environmental change - In: J. Canadell, D. Pataki, L. Pitelka (Eds.). Terrestrial ecosystems in a changing World. Pp. 115-124. Springer, Berlin.

Winer, B.J. - 1971 - Statistical principles in experimental design. 2nd ed. - McGraw-Hill, New York, USA.

Wittemberg, R. \& Cock, M.J.W. -2001 - Invasive alien species: a toolkit for best prevention and management practices - CABI, Wallingford. 